\title{
"Relationship" in Transition: An Introduction to the Special Issue on Relationship and Service- Dominant Logic
}

\author{
Stephen L. Vargo · Robert F. Lusch
}

This article introduces the special issue of the Journal of Business Market Management on relationship and service-dominant (S-D) logic (Vargo and Lusch 2004, 2008a). This special issue grew out of a double special session on the same topic at the 9th Conference on Relationship Marketing, sponsored by the Relationship Marketing Special Interest Group of the American Marketing Association and held in Berlin in 2009. The special session was motivated by our contention that many mainstream marketing terms take on different meanings when viewed from an S-D logic perspective rather than a goods-dominant (G-D) logic perspective. We thank Michael Kleinaltenkamp, Professor of Marketing at the Freie Universität Berlin, host for the conference and editor of this journal, for his interest in making the topic a plenary presentation and discussion focus, as well as the focus of this special issue.

The most obvious and critical of these conceptual transitions is found in the meaning of "service(s)," which in S-D logic becomes the process of using ones resources for the benefit of another party, expressed as the singular "service," rather than the traditional conceptualization of an intangible unit of output, usually referred to in the plural, "services." See Vargo and Lusch $(2008 \mathrm{a}, \mathrm{b})$ for further discussions of this conceptual transition.

Arguably, the importance of a related transition in the conceptualization of "relationship" is close behind that of "service(s)" in S-D logic. In fact, perhaps no other term is as potentially transformed by the shift in perspective. In G-D logic, with its emphases on units of output and transactions between producers and consumers, relationship has become conceptualized in terms of multiple transactions (see Vargo 2009). S-D logic, on the other hand, with its service-for-service, resource-integration perspective, represents a shift in thinking away from dyadic notions of production and consumption connected by transactional value delivery, toward the co-creation of value through complex, interac-

\author{
Published online: 23.10 .2010 \\ (C) Gabler-Verlag 2010 \\ S. L. Vargo $(\triangle)$ \\ University of Hawaii at Manoa, Honolulu, HI, USA \\ e-mail: svargo@hawaii.edu \\ R. F. Lusch \\ University of Arizona, Tucson, AZ, USA
}


tive, resource-integrating networks, especially including those associated with the service beneficiary. This, in turn, encourages zooming out to a service-ecosystem's view. From this perspective, relationship captures both the complexity and contextual nature of value creation and realization. This conceptual transition is discussed in our commentary "From Repeat Patronage to Value Co-Creation in Ecosystems: A Transcending Conceptualization of Relationship," which anchors this special issue.

Additionally, in this issue, Gummesson and Mele in "Marketing as Value-Co-creation through Network Interaction and Resource Integration," further explore the interactive, relational nature of value creation through resource-integration in networks. Chandler and Wieland extend this analysis by investigating the network embeddedness of relationships within other relationships in service ecosystems that is instrumental in the process of value creation and innovation in "Embedded Relationships: Implications for Networks, Innovation, and Ecosystems." Loebler, in "Signs and Practices: Coordinating Service and Relationships," takes a practice-theoretical approach to understanding the role of practices in assigning meaning to signs (symbols, signifiers), which in turn facilitate the coordination of service and relationships. In "The Relationship Marketing View of the Customer and the Service Dominant Logic Perspective," Gruen and Hofstetter argue that much of the transition from a G-D logic view to an S-D logic view has already taken place, especially in $\mathrm{B} 2 \mathrm{~B}$, relationship marketing practice, as evidenced by the adoption of co-production/co-creation approaches.

Together, these articles, along with the growing S-D logic literature being actively contributed to by numerous other scholars throughout the world, should assist in reframing core marketing concepts, such as "relationship" to provide a more robust insight through a wider, more comprehensive perspective. We encourage further work by all interested parties toward this goal.

\section{References}

Vargo, S. L. (2009). Toward a transcending conceptualization of relationship: A service-dominant logic perspective. Journal of Business \& Industry Marketing, 24(5/6), 373-379.

Vargo, S. L., \& Lusch, R. F. (2004). Evolving to a new dominant logic for marketing. Journal of Marketing, 68(January), 1-17.

Vargo, S. L., \& Lusch, R. F. (2008a). Service-dominant logic: Continuing the evolution. Journal of the Academy of Marketing Science, 36(1), 1-10.

Vargo, S. L., \& Lusch, R. F. (2008b). Why 'service'. Journal of the Academy of Marketing Science, 36(1), 25-38. 